Short communication

\title{
The roles of protein and lipid in the accumulation and distribution of perfluorooctane sulfonate (PFOS) and perfluorooctanoate (PFOA) in plants grown in biosolids-amended soils
}

\author{
Bei Wen ${ }^{\text {a, }}$, Yali Wu ${ }^{a}$, Hongna Zhang ${ }^{a}$, Yu Liu ${ }^{a}$, Xiaoyu Hu ${ }^{\text {b }}$, Honglin Huang ${ }^{\text {a }}$, \\ Shuzhen Zhang a \\ a State Key Laboratory of Environmental Chemistry and Ecotoxicology, Research Center for Eco-Environmental Sciences, Chinese Academy of Sciences, \\ Beijing, 100085, China \\ ${ }^{\mathrm{b}}$ Beijing Center for Disease Prevention and Control, Beijing, 100031, China
}

\section{A R T I C L E I N F O}

\section{Article history:}

Received 31 December 2015

Received in revised form

8 June 2016

Accepted 15 June 2016

Available online 2 July 2016

\section{Keywords:}

Plant

Accumulation

Distribution

PFASs

Protein

Lipid

\begin{abstract}
A B S T R A C T
The roles of protein and lipid in the accumulation and distribution of perfluorooctane sulfonate (PFOS) and perfluorooctanoate (PFOA) in seven species of plants from biosolids-amended soils were investigated. The PFOS and PFOA root concentration factors $\left(C_{\text {root }} / C_{\text {soil }}\right)$ ranged from 1.37 to 4.68 and 1.69 to 10.3 $\left(\mathrm{ng} / \mathrm{g}_{\text {root }}\right) /\left(\mathrm{ng} / \mathrm{g}_{\text {soil }}\right)$, respectively, while the translocation factors $\left(\mathrm{C}_{\text {shoot }} / \mathrm{C}_{\text {root }}\right)$ ranged from 0.055 to 0.16 and 0.093 to $1.8\left(\mathrm{ng} / \mathrm{g}_{\text {shoot }}\right) /\left(\mathrm{ng} / \mathrm{g}_{\text {root }}\right)$, respectively. The PFOS and PFOA accumulations in roots correlated positively with root protein contents $(P<0.05)$, while negatively with root lipid contents $(P<0.05)$. These suggested the promotion effects of protein and inhibition effects of lipid on root uptake. The translocation factors correlated positively with the ratios between protein contents in shoots to those in roots $(P<0.05)$, showing the importance of protein on PFOS and PFOA translocation. This study is the first to reveal the different roles of protein and lipid in the accumulation and distribution of PFOS and PFOA in plants.
\end{abstract}

() 2016 Elsevier Ltd. All rights reserved.

\section{Introduction}

Perfluoroalkyl substances (PFASs) are a class of emerging persistent organic pollutants (POPs). They have been manufactured and used in many industrial and household applications for more than half century. Within the PFAS group, perfluorooctane sulfonate (PFOS) and perfluorooctanoate (PFOA) are the most commonly used and found compounds (Arvaniti and Stasinakis, 2015). Up until now, PFOS and PFOA have been detected in all environmental and biological matrices, including the atmosphere (Wang et al., 2015; Ahrens et al., 2011; Dreyer et al., 2009), soil (Kim et al., 2015; Wen et al., 2014; Washington et al., 2010), water (Eschauzier et al., 2010; Bossi et al., 2008), sediment (Kwadijk et al., 2010), biota (Houde et al., 2011), and human serum (Gao et al., 2015). Adverse effects of PFOS and PFOA on plants, animals and humans have been reported (Wen et al., 2013; Stevenson et al.,

\footnotetext{
\& This paper has been recommended for acceptance by von Hippel Frank A.

* Corresponding author.

E-mail address: bwen@rcees.ac.cn (B. Wen).
}

2006). Due to their global distribution, environmental persistence, long distance transportation, and potential accumulation and toxicity, PFASs have been at the center of an increasing number of environmental monitoring studies.

Industrial and municipal wastewater treatment plants (WWTPs) are significant sources for dispersing PFASs into the environment (Kim et al., 2015; Wen et al., 2014; Washington et al., 2010; Bossi et al., 2008). High concentrations of PFASs have been found in the sludge from WWTPs (Vierke et al., 2013; Sun et al., 2011; Higgins et al., 2005). Land-application of biosolids (treated sludge) may lead to the accumulation of PFASs in soils, and consequently facilitate the entry of PFASs into the terrestrial food web by plant uptake (Wen et al., 2014; Sepulvado et al., 2011; Yoo et al., 2011; Washington et al., 2010). Both field and controlled laboratory studies have demonstrated that PFASs can be taken up from biosolids-amended soils, translocated and stored in different plant organs (Wen et al., 2014; Felizeter et al., 2014; Yoo et al., 2011; Blaine et al., 2014, 2013; Stahl et al., 2013; Lechner and Knapp, 2011). Soil organic carbon plays an important role in decreasing the accumulation of PFASs in plants (Wen et al., 2014; Yoo et al., 
2011). Accumulation and distribution of PFASs depend on plant species and varied with PFAS properties. Radish and celery showed preference for uptake of short perfluorinated carbon-chain of PFASs. However, wheat, sugar snap pea and tomato showed no preference for uptake of PFASs with different perfluorinated carbon-chain (Wen et al., 2014; Blaine et al., 2014). Translocation from roots to the above ground part of plants showed a decrease with increasing PFAS carbon chain length (Wen et al., 2014; Blaine et al., 2014; Felizeter et al., 2014). As a result, long-chain PFASs are mainly distributed in plant roots, while short-chain PFASs are mainly found in leaves and fruits (Felizeter et al., 2014). Blaine et al. (2014) reported that PFOS root to shoot translocation factors (TFs) from roots to shoots were less than 1 for celery and tomato, and were more than 1 for radish and pea.

Bioaccumulation of hydrophobic organic compounds (HOCs) in plants, such as polycyclic aromatic hydrocarbons (PAHs) and polychlorinated biphenyls (PCBs) is mainly characterized by lipid dominating partition processes. Lipid is the major reservoir for accumulation of HOCs in plant (Chiou et al., 2001; Li et al., 2010). Huang et al. (2010) reported that root concentration factors (RCFs) of HOCs correlated positively with root lipid contents, while TFs correlated negatively with root lipid contents. PFASs are ionizable organic pollutants and mainly exist as anions in environmental relevant $\mathrm{pH}$ conditions. They tend to accumulate in protein-rich tissues in fish and animals, such as liver and blood, rather than in fat tissues (Hoff et al., 2003). Wen et al. (2013) found that the kinetics of PFOS and PFOA uptake by plant fitted Mechaelis-Menten equation well, suggesting their transport protein-mediated influx processes. In contrast, Felizeter et al. (2012) suggested that uptake of PFASs by lettuce root was mainly governed by sorption to lipidrich root solids. Though species-dependent uptake and tissue distribution of PFASs in plants have been reported, there is still limited mechanistic understanding of the biotic parameters on PFASs accumulation in plants.

In this study, we conducted a greenhouse pot experiment to explore the uptake and translocation of PFOS and PFOA in seven species of plants from biosolids-amended soil. Protein and lipid contents in plant roots and shoots were determined in order to test their influences. To the best of our knowledge, this is the first attempt to elucidate the roles of protein and lipid on the accumulation and distribution of PFOS and PFOA in plant.

\section{Experimental section}

\subsection{Materials}

Perfluorooctanesulfonic acid (potassium salt, > 98\%), perfluorooctanoic acid (PFOA, > 96\%), tetrabutylammonium hydrogen sulfate (TBAHS, > 99\%), sodium carbonate (>99\%), sodium hydroxide $(>98 \%)$ and ammonium acetate (>99\%) were purchased from Sigma-Aldrich Chemical Co. (Milwaukee, WI, USA). HPLCgrade methyl tert-butyl ether (MTBE, $>99.9 \%$ ), chloroform, hexane, acetonitrile and methanol were from Fisher Scientific Co. (Fair Lawn, NJ, USA). Surrogate standards $\left({ }^{13} \mathrm{C}_{4}\right.$-PFOA and ${ }^{13} \mathrm{C}_{4}$-PFOS) were purchased from Wellington Laboratories Inc. (Guelph, Ontario, Canada) and were used as-received. Milli-Q water was applied throughout the experimental work.

\subsection{Biosolids-amended soil}

Biosolids-amended soil was collected from surface layer $(0-20 \mathrm{~cm})$ of biosolids-amended agricultural fields in Dezhou Experiment Station, Chinese Academy of Agricultural Sciences (Dezhou, Shandong province, China). The soil has received municipal biosolids at the rate of 20 tons (dry matter) per hectare per year for more than nine years. Uncontaminated soil without detectable PFOS and PFOA was collected from an experimental field at Beijing Academy of Agriculture and Forestry Sciences. The soil samples were air-dried and sieved through a 2-mm fiber sieve to remove stones, plant roots, and other large particles prior to the determination of PFOS and PFOA and pot experiments. The selected properties and PFOS and PFOA concentrations in the soils are given in Table 1.

\subsection{Pot experiment}

Maize (Zea mays L. cv. Nongda 108), soybean (Glycine max L. Merrill), radish (Raphnus sativus L. cv. Dahongpao), mung bean (Vigna radiata L. Wilczek), lettuce (Lactuca sativa L.), alfalfa (Medicago sativa L. Cv. Chaoren) and Italian ryegrass (Lolium multiflorum Lam.) were used as test plants. Seeds were purchased from the Chinese Academy of Agricultural Sciences, Beijing, China. They were sterilized in $10 \%(\mathrm{w} / \mathrm{w}) \mathrm{H}_{2} \mathrm{O}_{2}$ solution for $15 \mathrm{~min}$, thoroughly washed with Milli-Q water, soaked in a $3 \mathrm{mM}$ solution of $\mathrm{Ca}\left(\mathrm{NO}_{3}\right)_{2}$ for $6 \mathrm{~h}$ in the dark, and subsequently germinated on moist filter paper in the dark.

Each polypropylene pot (upper diameter $18 \mathrm{~cm}$, lower diameter $12.8 \mathrm{~cm}$, height $16 \mathrm{~cm}$ ) received $1.5 \mathrm{~kg}$ of soil. Polypropylene bags were placed inside the pots to prevent contamination and water drainage. Twenty pregerminated seeds were sown in each pot. After emergence for 3 days the seedlings were thinned to 18 (ryegrass), 15 (alfalfa), and 5 (maize, soy bean, lettuce, green bean and radish). Pots were kept in a controlled environment growth chamber for $45 \mathrm{~d}$ at a light intensity of $250 \mu \mathrm{mol} \mathrm{m} \mathrm{m}^{-2} \mathrm{~s}^{-1}$ provided by supplementary illumination with a photoperiod of $14 \mathrm{~h}$ each day, at a $25 / 20{ }^{\circ} \mathrm{C}$ day/night temperature regime, and a relative humidity of $70 \%$. Plants in uncontaminated soil grown in the same chamber as those in biosolids-amended were set up as control. Plants in uncontaminated soil grown in another chamber were set up as blank. Four replicate pots of each treatment were prepared. The pots were positioned randomly and randomized every two days. Milli-Q water was added as required to maintain moisture content at $60-70 \%$ of water holding capacity by regular weighing.

\subsection{Sample preparation}

Plant shoots above ground and roots below ground were harvested separately after growth for $45 \mathrm{~d}$. Root samples were carefully washed with tap water to remove any adhering soil particles. Then root and shoot samples were thoroughly rinsed with Milli-Q water, blotted with tissue paper and weighed. The protein contents in fresh roots and shoots were determined. Plant tissues were then frozen at $-80{ }^{\circ} \mathrm{C}$ overnight, freeze-dried for $48 \mathrm{~h}$ in a lyophilizer (FD-1, Beijing Boyikang Instrument Ltd., Beijing, China) and weighed again. The water contents of roots and shoots are calculated by mass balance. The lipid contents in dry roots and shoots were determined. The dried root and shoot samples were ground and stored in polypropylene pot containers at $-20{ }^{\circ} \mathrm{C}$ before chemical analysis.

\subsection{Determination of protein and lipid contents in plant roots and shoots}

Protein contents in fresh plant roots and shoots were determined according to the method of Jones et al. (1989) with some modifications. Lipid contents in dried roots and shoots were determined following the same principles as employed previously in our laboratory (Zhu et al., 2007). Information of protein and lipid determination was given in Supplementary materials. 
Table 1

Selected properties and concentrations of PFOS and PFOA in control and biosolids-amended soils.

\begin{tabular}{|c|c|c|c|c|c|c|c|c|c|}
\hline Soils & Order & PFOS $\left(\right.$ ng g $\left.^{-1}\right)$ & PFOA (ng $\left.g^{-1}\right)$ & $\mathrm{pH}^{\mathrm{a}}$ & $\mathrm{OC}^{\mathrm{b}}(\%)$ & $\mathrm{CEC}^{\mathrm{C}}\left(\mathrm{cmol} \mathrm{kg}^{-1}\right)$ & Clay (\%) & Silt (\%) & Sand (\%) \\
\hline Control & Mollisols & $<\mathrm{MLQ}^{\mathrm{d}}$ & $<$ MLQ & 7.36 & 1.01 & 25.0 & 7.79 & 59.1 & 33.1 \\
\hline Biosolids- amended soil & Mollisols & $154.4(18.6)^{\mathrm{e}}$ & $416.8(29.5)$ & 8.26 & 1.93 & 42.6 & 9.91 & 79.4 & 10.7 \\
\hline
\end{tabular}

References:

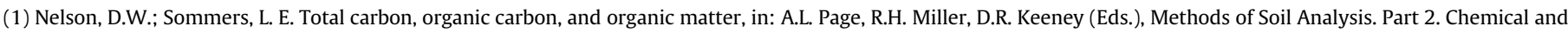
microbiological properties, 2nd ed., ASA and SSSA, Madison, WI, 1982, pp. 539-579.

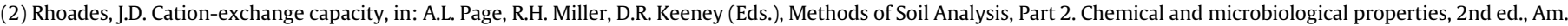
Soc. Agron., Madison, WI, 1982, pp. 149-158.

a Soil pH was measured in $\mathrm{CaCl}_{2}(0.01 \mathrm{M})$ at a soil to solution ratio of $1: 5(\mathrm{w}: \mathrm{v})$.

b Organic carbon content was determined by the Walkley-Black procedure. ${ }^{1}$.

c Cation-exchange capacity (CEC) was determined by the method of Rhoades (1982). ${ }^{2}$.

d PFOS and PFOA values are under detect limits.

e Standard deviation.

\subsection{Chemical extraction and UPLC-MS/MS analysis}

PFOS and PFOA were extracted from soils and plant tissues by MTBE-NaOH according to the method we previously employed (Wen et al., 2014). Before extraction, surrogate standards, ${ }^{13} \mathrm{C}_{4}$-PFOS and ${ }^{13} \mathrm{C}_{4}$-PFOA, were spiked. There were four replicates per treatment. An ultra-high performance liquid chromatography tandem mass spectrometry (UPLC-MS/MS, Waters Corp., USA) was used to determine PFOS and PFOA. Optimized UPLC-MS/MS parameters for the determination of PFOS and PFOA in samples were given in Table S1. Detailed information about the sample analysis was provided in Supplementary materials.

\subsection{Quality assurance and quality control measures}

Quality control was done by regular analyses of procedural blanks, blind duplicate samples, and random injection of solvent blanks and standards. Blank matrix was obtained from uncontaminated soils and plants cultured in uncontaminated soils. Matrix calibration curves using spiked uncontaminated samples that were extracted in analogy to the samples were applied for quantification. An eighteen-point calibration line was used for quantification. The fitted lines had $\mathrm{r}^{2}$ values of at least 0.99 for all analytes. The method limits of quantification (MLQs) were calculated with the formula MLQ $=\mathrm{y}_{0}+10 \sigma\left(\mathrm{y}_{0}\right.$, average of measured values for the blank matrix; $\sigma$, standard deviation of the measured values for the blank matrix). MLQs were measured for each matrix on replicate analyses $(n=6)$ of blank samples. All samples were injected in triplicates. For PFOS, MLQs were $0.16 \mathrm{ng} \mathrm{g}^{-1}$ dry weight (DW) in soil and $0.25-0.35 \mathrm{ng} \mathrm{g}^{-1} \mathrm{DW}$ in plant tissues. For PFOA, MLQs were $0.10 \mathrm{ng} \mathrm{g}^{-1} \mathrm{DW}$ in soil and $0.21-0.30 \mathrm{ng} \mathrm{g}^{-1} \mathrm{DW}$ in plant tissues (Table S2). The accuracy of PFOS and PFOA determination was assessed by testing the recoveries of ${ }^{13} \mathrm{C}_{4}$-PFOS and ${ }^{13} \mathrm{C}_{4}$-PFOA. The recoveries of ${ }^{13} \mathrm{C}_{4}$-PFOS and ${ }^{13} \mathrm{C}_{4}$-PFOA were $89-105$ and $92-108 \%$, respectively (Fig. S1).

\subsection{Bioaccumulation metrics and data analysis}

RCFs ((ng/g root $\left.) /\left(n g / g_{\text {soil }}\right)\right)$, shoot concentration factors (SCFs, $\left.\left(\mathrm{ng} / \mathrm{g}_{\text {shoot }}\right) /\left(\mathrm{ng} / \mathrm{g}_{\text {soil }}\right)\right)$, and TFs $\left(\left(\mathrm{ng} / \mathrm{g}_{\text {shoot }}\right) /\left(\mathrm{ng} / \mathrm{g}_{\text {root }}\right)\right)$ were calculated according to Eqs. (1)-(3), respectively.

$$
\begin{aligned}
& \text { RCFs }=C_{\text {root }} / C_{\text {soil }} \\
& \text { SCFs }=C_{\text {shoot }} / C_{\text {soil }} \\
& \text { TFs }=C_{\text {shoot }} / C_{\text {root }}
\end{aligned}
$$

Where $\mathrm{C}_{\text {root }}, \mathrm{C}_{\text {shoot }}$ and $\mathrm{C}_{\text {soil }}$ are concentrations of PFOS or PFOA in roots, shoots, and soil, respectively. All statistical analyses were conducted with the software Origin 8. One-way ANOVA was used to assess the significance of the difference between groups, and a linear regression technique was used to derive the relationships among variables. Statements of significant differences are based on $\mathrm{P}<0.05$.

\section{Results and discussion}

\subsection{Uptake, translocation and distribution of PFOS and PFOA in plants}

The average dry weights and water contents of plants grown in biosolids-amended soil are slightly higher than those in control soil, but it was within the statistic ranges (Table S3). PFOS and PFOA were found in all plants grown in biosolids-amended soil (Table 2), neither compound was found in control plants (data not shown). Organic contaminants reach aerial plant organs in two ways: from the air and with the transpiration stream (Huang et al., 2010). The finding of no detectable PFOS and PFOA levels was found in control plants suggested that the aerial uptake of PFOS and PFOA on their accumulation is negligible. Similar results of no significant contribution from aerial uptake to PFOS and PFOA concentrations in plant shoots were reported by Zhao et al. (2014).

Accumulation and distribution of PFOS and PFOA in plants are plant species-dependent (Table 2). Among plants studied, the PFOS concentrations in roots decreased in the order of soybean

Table 2

Concentration of PFOS and PFOA in plant roots and shoots on dry weight basis $\left(\mathrm{ng} \mathrm{g}^{-1}\right)$, root concentration factors $\left(\mathrm{RCF}=\mathrm{C}_{\text {root }} / \mathrm{C}_{\text {soil }},\left(\mathrm{ng} / \mathrm{g}_{\text {root }}\right) /\left(\mathrm{ng} / \mathrm{g}_{\text {soil }}\right)\right)$, shoot concentration factors $\left(\mathrm{SCF}=\mathrm{C}_{\text {shoot }} / \mathrm{C}_{\text {soill }},\left(\mathrm{ng} / \mathrm{g}_{\text {shoot }}\right) /\left(\mathrm{ng} / \mathrm{g}_{\text {soil }}\right)\right)$ and translocation factors $\left(\mathrm{TF}=\mathrm{C}_{\text {shoot }} / \mathrm{C}_{\text {root }},\left(\mathrm{ng} / \mathrm{g}_{\text {shoot }}\right) /\left(\mathrm{ng} / \mathrm{g}_{\text {root }}\right)\right)$.

\begin{tabular}{lcccll}
\hline \multicolumn{1}{c}{} & $\mathrm{C}_{\text {root }}$ & \multicolumn{1}{l}{$\mathrm{C}_{\text {shoots }}$} & $\mathrm{RCF}$ & $\mathrm{SCF}$ & $\mathrm{TF}$ \\
\hline PFOS (soil: & $154.4 \pm 18.6 \mathrm{ng} / \mathrm{g})$ & & & & \\
Alfalfa & $481.4(6.7)$ & $62.9(7.3)$ & 3.12 & 0.407 & 0.131 \\
Lettuce & $600.8(63.4)$ & $61.2(5.3)$ & 3.89 & 0.396 & 0.102 \\
Maize & $408.9(37.7)^{\mathrm{a}}$ & $25.5(4.4)$ & 2.65 & 0.165 & 0.0624 \\
Mung bean & $640.2(41.4)$ & $105.5(8.9)$ & 4.14 & 0.683 & 0.165 \\
Radish & $403.2(56.1)$ & $72.3(17.8)$ & 2.61 & 0.468 & 0.179 \\
Ryegrass & $212.4(29.8)$ & $27.9(3.5)$ & 1.37 & 0.181 & 0.131 \\
Soybean & $723.6(54.9)$ & $39.9(2.8)$ & 4.68 & 0.258 & 0.0551 \\
PFOA (soil: $416.8 \pm 29.5 \mathrm{ng} / \mathrm{g})$ & & & & \\
Alfalfa & $4310.3(303.0)$ & $1311.5(201.1)$ & 10.3 & 3.15 & 0.304 \\
Lettuce & $2523.2(251.4)$ & $493.6(42.7)$ & 6.05 & 1.18 & 0.196 \\
Maize & $703.4(38.1)$ & $85.8(2.4)$ & 1.69 & 0.206 & 0.122 \\
Mung bean & $3230.1(292.8)$ & $3500.9(166.3)$ & 7.75 & 8.40 & 1.08 \\
Radish & $1250.3(169.2)$ & $2227.4(54.3)$ & 3.00 & 5.34 & 1.78 \\
Ryegrass & $977.8(88.7)$ & $550.8(59.0)$ & 2.35 & 1.32 & 0.563 \\
Soybean & $1335.9(100.4)$ & $123.6(11.8)$ & 3.21 & 0.296 & 0.0930 \\
\hline
\end{tabular}

a Standard deviation $(\mathrm{n}=4)$. 
Table 3

Contents of protein and lipid in plant roots and shoots on dry weight basis (\%).

\begin{tabular}{llllll}
\hline & Protein & & & Lipid \\
\cline { 2 - 3 } \cline { 5 - 6 } & Roots & Shoots & & Roots & Shoots \\
\hline Alfalfa & $8.23 \pm 0.59$ & $16.9 \pm 1.3$ & & $2.33 \pm 0.15$ & $12.3 \pm 1.31$ \\
Lettuce & $7.40 \pm 0.40$ & $19.5 \pm 0.8$ & & $2.15 \pm 0.21$ & $6.45 \pm 0.37$ \\
Maize & $3.78 \pm 0.08^{\mathrm{a}}$ & $6.37 \pm 0.51$ & & $4.35 \pm 0.31$ & $9.39 \pm 0.87$ \\
Mung bean & $10.4 \pm 0.08$ & $29.1 \pm 1.5$ & & $2.51 \pm 0.18$ & $6.37 \pm 0.55$ \\
Radish & $4.45 \pm 0.24$ & $13.3 \pm 1.1$ & & $3.34 \pm 0.21$ & $6.08 \pm 0.57$ \\
Ryegrass & $3.35 \pm 0.10$ & $7.55 \pm 0.66$ & & $5.40 \pm 0.17$ & $7.44 \pm 0.25$ \\
Soybean & $8.00 \pm 0.51$ & $15.9 \pm 0.98$ & & $2.45 \pm 0.16$ & $10.3 \pm 0.95$ \\
\hline
\end{tabular}

a Mean value \pm the standard deviation $(n=4)$.

$\left(723.6 \pm 54.9 \mathrm{ng} \mathrm{g}^{-1}\right)>$ mung bean $\left(640.2 \pm 41.4 \mathrm{ng} \mathrm{g}^{-1}\right)>$ lettuce $\left(600.8 \pm 63.4 \mathrm{ng} \mathrm{g}^{-1}\right)>$ alfalfa $\left(481.4 \pm 6.7 \mathrm{ng} \mathrm{g}^{-1}\right)>$ maize $\left(408.9 \pm 37.7 \mathrm{ng} \mathrm{g}^{-1}\right) \geq \operatorname{radish}\left(403.2 \pm 56.1 \mathrm{ng} \mathrm{g}^{-1}\right)>$ ryegrass $\left(212.4 \pm 29.8 \mathrm{ng} \mathrm{g}^{-1}\right)$, while the PFOA concentrations in roots decreased in the order of alfalfa $\left(4310.3 \pm 303.0 \mathrm{ng} \mathrm{g}^{-1}\right)>$ mung bean (3230.1 $\left.\quad \pm \quad 292.8 \quad \mathrm{ng} \quad \mathrm{g}^{-1}\right) \quad>\quad$ lettuce $\left(2523.2 \pm 251.4 \mathrm{ng} \mathrm{g}^{-1}\right)>$ soybean $\left(1335.9 \pm 100.4 \mathrm{ng} \mathrm{g}^{-1}\right) \geq$ radish $\left(1250.3 \pm 169.2 \mathrm{ng} \mathrm{g}^{-1}\right)>$ ryegrass $\left(977.8 \pm 88.7 \mathrm{ng} \mathrm{g}^{-1}\right)>$ maize $\left(703.4 \pm 38.1 \mathrm{ng} \mathrm{g}^{-1}\right)$. Though the concentrations of PFOS and PFOA in the roots of different plant species did not followed the same order, PFOS and PFOA concentrations in radish, maize and ryegrass roots were lower than in other species. The RCFs of PFOS ranged 1.37-4.68 (ng/g $\left./ \mathrm{g}_{\text {root }}\right) /\left(\mathrm{ng} / \mathrm{g}_{\text {soil }}\right)$, while those of PFOA ranged $1.69-10.3\left(\mathrm{ng} / \mathrm{g}_{\text {root }}\right) /\left(\mathrm{ng} / \mathrm{g}_{\text {soil }}\right)$. The RCFs of PFOA were higher than those of PFOS for all plant species except for maize and soybean.

The SCFs of PFOS were lower than $1\left(\mathrm{ng} / \mathrm{g}_{\text {shoot }}\right) /\left(\mathrm{ng} / \mathrm{g}_{\text {root }}\right)$ for all plant species, while those of PFOA were higher than $1\left(\mathrm{ng} / \mathrm{g}_{\text {shoot }}\right) /$ (ng/groot) except for maize and soybean (Table 2). The TFs of PFOA were 1.7-9.9 times those of PFOS. The transport of POPs from roots to stems was mainly governed through transpiration (Murano et al., 2010). POPs with larger molecular size and higher lipophilicity are more difficult to translocate from root to shoot (Satchivi et al., 2006). The relatively lower TFs of PFOS when compared with those of PFOA suggested that binding of PFOS to roots is stronger than that of PFOA, thus transfer potential from roots to shoots of PFOS was lower than that of PFOA. The strong binding may be due to the relatively large molecule and/or lipophilicity of PFOS when compared with PFOA. Blaine et al. $(2014,2013)$ and Felizeter et al. (2014) also reported that the TFs values of PFOA were higher than

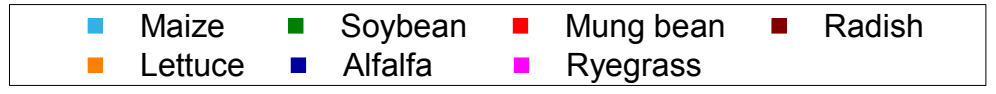
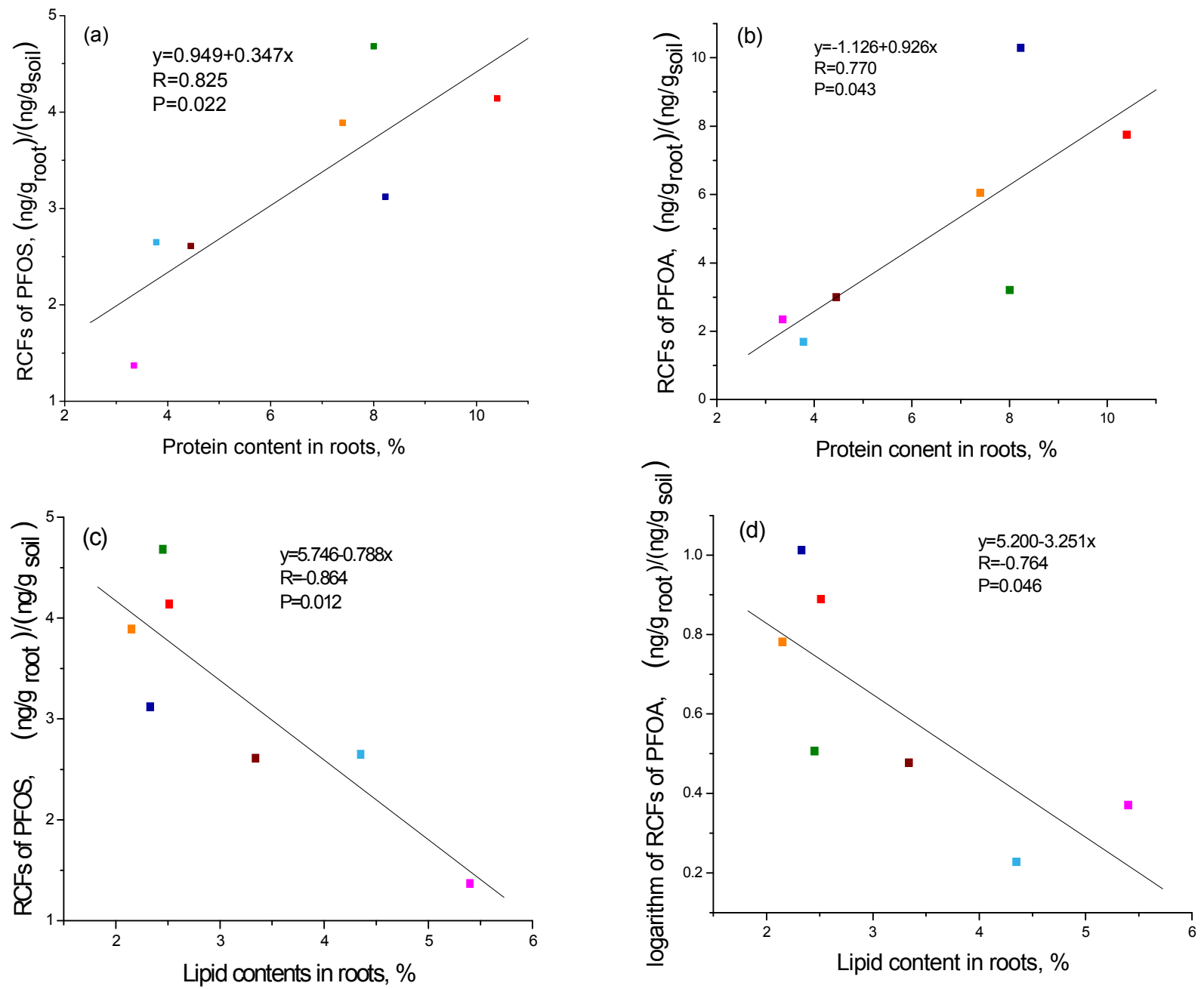

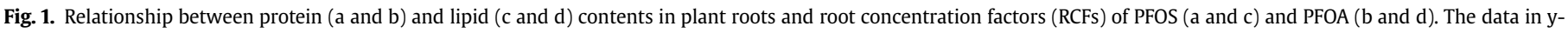
axis of $1 \mathrm{~d}$ is in a logarithm scale. 


$\begin{array}{lllll}\text { Maize } & \text { Soybean } & \text { S } & \text { Mung bean } \\ \text { Lettuce } & \text { Alfalfa } & \text { ayegrass }\end{array}$
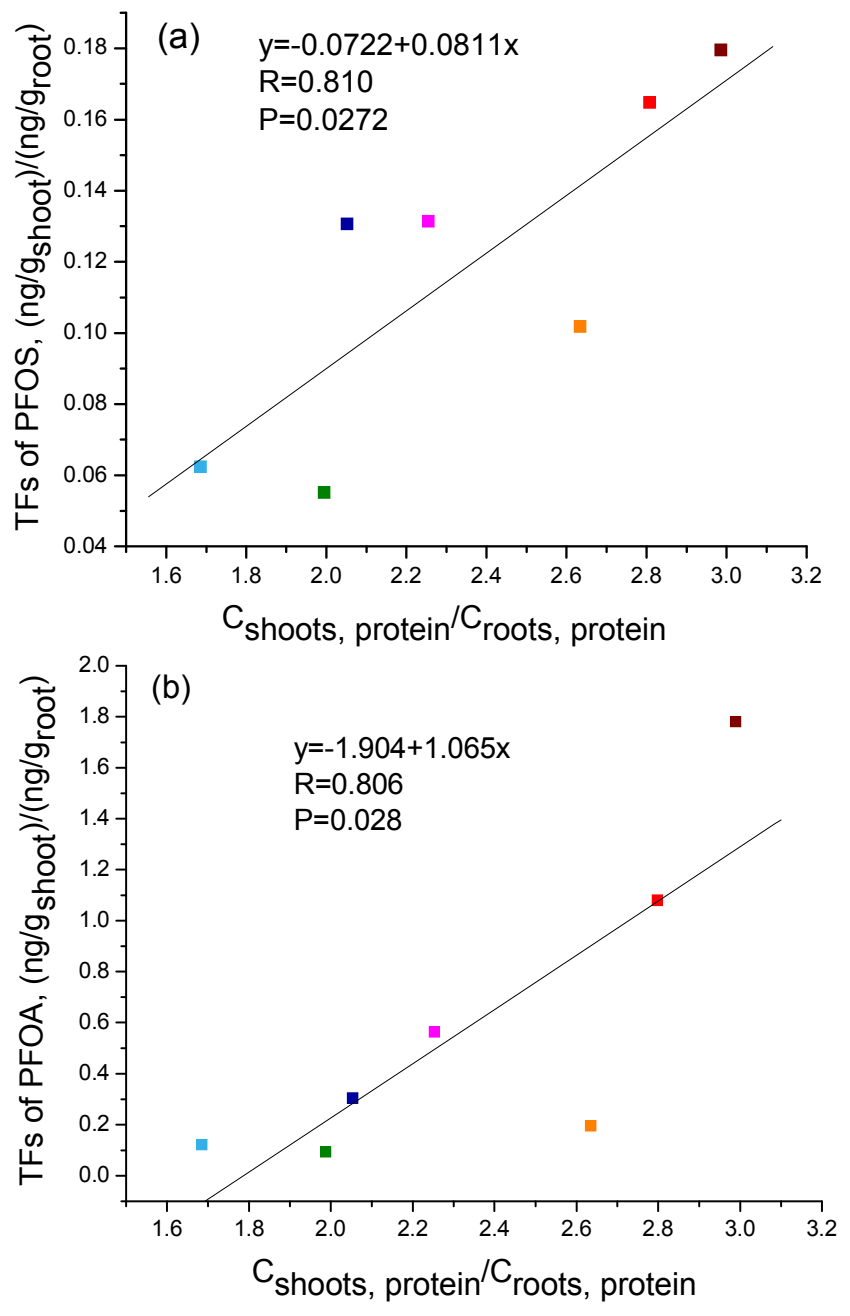

Fig. 2. Relationship between translocation factor (TF) values from roots to shoots and the ratio of shoot protein to root protein contents of PFOS (a) and PFOA (b).

those of PFOS. Among plants studied, the TFs of radish were the highest. Blaine et al. (2014) found that PFASs in radish shoot were about 5-10 times higher than those in tomato, pea and celery, and ascribed it to the lack of the typical Casparian strip between roots and the above ground shoots of radish. The mass distributions of PFOS and PFOA in plant roots and shoots are shown in Fig. S2. PFOS mainly presented in roots of all plant species, which account for $55-89 \%$ of total PFOS in plants, while mass distribution of PFOA depended on plant species. PFOA mainly presented in shoots for radish, ryegrass and mung bean, while mainly presented in root for maize, soybean, lettuce and alfalfa. Although amount of PFOS and PFOA in radish roots were not the highest among plants studied, precaution has to be exercised as humans consume radish roots directly.

\subsection{Relationships between the contents of protein and lipid and the concentrations of PFOS and PFOA in plants}

Protein and lipid contents in plant shoots and roots are shown in Table 3. Protein contents in plant dry tissues were calculated by dividing protein contents in fresh tissues by tissue water contents.
The protein contents in roots and shoots ranged from 3.35 to $10.4 \%$ and $6.37-29.1 \%$, respectively, while the lipid contents in roots and shoots ranged from 2.15 to $5.40 \%$ and $6.08-12.3 \%$, respectively (Table 3). Among plants studied, protein contents in the roots of radish, maize and ryegrass (3.35-4.45\%) were lower than the other species (7.40-10.4\%), which were consistent with their relatively low PFOS and PFOA concentrations. This indicated that protein and lipid in roots may have different effects on the root accumulation of PFOS and PFOA. Protein content in mung bean shoots was the largest, while that in maize shoot was the lowest among seven plant species, which was consistent with the largest PFOS and PFOA SCFs of mung bean and lowest PFOS and PFOA SCFs of maize. These data suggest that protein may play an important role in accumulation of PFOS and PFOA in plant shoots.

Correlation analysis was conducted to further elucidate the roles of protein and lipid in the accumulation and distribution of PFOS and PFOA in plants. PFOS and PFOA RCFs correlated positively with root protein contents $(\mathrm{P}<0.05$, Fig. $1 \mathrm{a}$ and $\mathrm{b})$, suggesting the promotion effect of protein on the accumulation of PFOS and PFOA in roots. PFOS RCFs correlated negatively with root lipid contents $(P<0.05$, Fig. 1c). Similar negative relationship between root lipid contents and logarithm of PFOA RCFs was observed $(\mathrm{P}<0.05$, Fig. 1d). These indicated the inhibiting effect of lipid on the accumulation of PFOS and PFOA in roots. The inhibiting effect was more severe for PFOA than for PFOS.

There are two prevailing hypotheses for the mechanism controlling PFAS bioaccumulation and distribution in mammals, birds and fish, partitioning to neutral and membrane phospholipids and interaction with specific proteins ( $\mathrm{Ng}$ and Hungerbuehler, 2013; 2014; Armitage et al., 2013). The distribution of PFASs in proteinrich tissues, rather than in fat tissues, and the high affinity to some proteins highlighted the proteinophilic nature of PFASs (Zhang et al., 2013; Bischel et al., 2011, 2010). Though the serum proteins do not exist in plants, fatty acid binding proteins have been found in plants (Arondel et al., 1990; Rickers et al., 1984). Moreover, in vitro studies have shown that PFASs associated strongly with plant protein, soy peptone (Xia et al., 2013). Although the properties of PFASs binding protein in plants were not clear, the findings of positive correlations between PFASs and protein contents suggested that the interaction with proteins is the key mechanism responsible for accumulation of PFOS and PFOA in plant roots.

Plant lipids determined included neutral lipids, phospholipids and fatty acids (Bai et al., 2010; Guo et al., 2005; Rizov and Doulis, 2001). Armitage et al. (2012) proposed that phospholipids may dominate the contribution of total lipid to an organism's sorption capacity for PFASs due to their zwitterionic properties, which are similar to those of protein. However, in this study, lipids were found to inhibit the accumulation of PFOS and PFOA in roots. It is reported that free fatty acids could affect the bindings between endogenous or exogenous compounds and proteins (Fujiwara and Amisaki, 2013; Spector et al., 1973). The inhibitory ability depends on the binding strength of the particular compound to proteins. In-vitro studies showed that PFOA was bound much less firmly to plant protein than PFOS (Xia et al., 2013). Based on the findings reported, one could estimate that lipid may compete with the binding sites of PFOS and PFOA on root protein, which limited the accumulation of PFOS and PFOA in roots. The relatively lower sorption capacity of PFOA may be responsible for the more severe inhibition.

Shoot concentration factors correlated positively with shoot protein contents for PFOS ( $\mathrm{P}<0.05$, Fig. S3a), but did not correlated significantly with shoot lipid contents ( $\mathrm{p}>0.05$, data not shown). The SCFs of PFOA increased with the increment of shoot protein contents, however, no significant correlation was found $(P>0.05$, Fig. S3b). The TFs of PFOS and PFOA correlated positively with the ratios of shoot protein to root protein contents (Fig. 2). No 
correlation between TFs and the ratios of lipid contents between shoots and roots was found (data not shown). This indicated that tissue distribution of PFASs in plants was mainly characterized by protein transport process.

\section{Conclusion}

The results from this study demonstrated the important role of protein in controlling uptake, translocation and tissue distribution of PFASs in plants, though an exact explanation for the observed effect remains to be proven. To the best of our knowledge, this is the first study which explores the specific roles of protein and lipid on the bioaccumulation of PFASs in plants. More studies are required to detail the interactions between plant protein and structurally different PFASs, and the effect of plant fatty acids on the adsorption of PFASs on plant proteins.

\section{Acknowledgements}

We thank Dr. Pearlie low Sijia of Nanyang Technological University for the English polishing, comments and suggestions on the manuscript. The study was supported by the National Natural Science Foundation (Project 21537005, 41371460 and 21321004) and the Strategic Priority Research Program of the Chinese Academy of Sciences (XDB14020202).

\section{Appendix A. Supplementary data}

Supplementary data related to this article can be found at http:// dx.doi.org/10.1016/j.envpol.2016.06.032.

\section{References}

Ahrens, L., Shoeib, M., Harner, T., Lee, S.C., Guo, R., Reiner, E.J., 2011. Wastewater treatment plant and landfills as sources of polyfluoroalkyl compounds to the atmosphere. Environ. Sci. Technol. 45, 8098-8105.

Armitage, J.M., Arnot, J.A., Wania, F., Mackay, D., 2013. Development and evaluation of a mechanistic bioconcentration model for ionogenic organic chemicals in fish. Environ. Toxicol. Chem. 32, 115-128.

Armitage, J.M., Arnot, J.A., Wania, F., 2012. Potential role of phospholipids in determining the internal tissue distribution of perfluoroalkyl acids in biota. Environ. Sci. Technol. 46, 12285-12286.

Arondel, V., Vergnolle, C., Tchang, F., Kader, J.C., 1990. Bifunctional lipid-transfer: fatty acid-binding proteins in plants. Mol. Cell. Biochem. 98, 49-56.

Arvaniti, O.S., Stasinakis, A.S., 2015. Review on the occurrence, fate and removal of perfluorinated compounds during wastewater treatment. Sci. Total Environ. $81-92,524-525$

Bai, X.W., Song, C.H., You, J.M., Sun, ZW., Fu, YY., Li, G.L., 2010. Determination of fatty acids $\left(C_{1}-C_{10}\right)$ from bryophytes and pteridophytes. Chromatographia 71 , 1125-1129.

Blaine, A.C., Rich, C.D., Sedlacko, E.M., Hundal, L.S., Kumar, K., Lau, C., Mills, M.A., Harris, K.M., Higgins, C.P., 2014. Perfluoroalkyl acid distribution in various plant compartments of edible crops grown in biosolids-amended soils. Environ. Sci. Technol. 48, 7858-7865.

Blaine, A.C., Rich, C.D., Hundal, L.S., Lau, C., Mills, M.A., Harris, K.M., Higgins, C.P., 2013. Uptake of perfluoroalkyl acids into edible crops via land applied biosolids: field and greenhouse studies. Environ. Sci. Technol. 47, 14062-14069.

Bischel, H.N., MacManus-Spencer, LA. Zhang C., Luthy, R.G., 2011. Strong associations of short-chain perfluoroalkyl acids with serum albumin and investigation of binding mechanisms. Environ. Toxicol. Chem. 30, 2423-2430.

Bischel, H.N., Macmanus-Spencer, L.A., Luthy, R.G., 2010. Noncovalent interactions of long-chain perfluoroalkyl acids with serum albumin. Environ. Sci. Technol. 44, 5263-5269.

Bossi, R., Strand, J., Sortkær, O., Larsen, M.M., 2008. Perfluoroalkyl compounds in Danish wastewater treatment plants and aquatic environments. Environ. Int. 34, 443-450.

Chiou, C.T., Sheng, G.Y., Manes, M., 2001. A partition-limited model for the plant uptake of organic contaminants from soil and water. Environ. Sci. Technol. 35, 1437-1444.

Dreyer, A., Weinberg, I., Temme, C., Ebinghaus, R., 2009. Polyfluorinated compounds in the atmosphere of the Atlantic and Southern oceans: evidence for a global distribution. Environ. Sci. Technol. 43, 6507-6514.

Eschauzier, C., Haftka, J., Stuyfzand, P.J., de Voogt, P., 2010. Perfluorinated compounds in infiltrated river rhine water and infiltrated rainwater in coastal dunes. Environ. Sci. Technol. 44, 7450-7455.
Felizeter, S., McLachlan, M.S., de Voogt, P., 2012. Uptake of perfluorinated alkyl acids by hydroponically grown lettuce (Lactuca sativa). Environ. Sci. Technol. 46, $11735-11743$.

Felizeter, S., McLachlan, M.S., De Voogt, P., 2014. Root uptake and translocation of perfluorinated alkyl acids by three hydroponically grown crops. J. Agric. Food Chem. 62, 3334-3342.

Fujiwara, S., Amisaki, T., 2013. Fatty acid binding to serum albumin: molecular simulation approaches. Biochim. Biophys. Acta 1830, 5427-5434.

Gao, Y., Fu, J.J., Cao, H.M., Wang, Y.W., Zhang, A.O., Liang, Y., Wang, T., Zhao, C.Y., Jiang, G.B., 2015. Differential accumulation and elimination behavior of perfluoroalkyl acid isomers in occupational workers in a manufactory in China. Environ. Sci. Technol. 49, 6953-6962.

Guo, B.Y., Wen, B., Shan, X.Q., Zhang, S.Z., Lin, J.M., 2005. Separation and determination of phospholipids in plant seeds by nonaqueous capillary electrophoresis. J. Chromatography A 1074, 205-213.

Higgins, C.P., Field, J.A., Criddle, C.S., Luthy, R.G., 2005. Quantitative determination of perfluorochemicals in sediments and domestic sludge. Environ. Sci. Technol. 39, 3946-3956.

Hoff, P.T., Van de Vijver, K., Dongen, W.V., Esmans, E.L., Blust, R., De Coen, W.M., 2003. Perfluorooctane sulfonic acid in Bib (Trisopterus Luscus) and plaice (Pleuronectes platessa) from the western Scheldt and the Belgian north sea: distribution and biochemical effects. Environ. Toxicol. Chem. 22, 608-614.

Houde, M., De Silva, M.O., Derek, C.G., Muir, D.C.G., Letcher, R.J., 2011. Monitoring of perfluorinated compounds in aquatic biota: an updated reviews. Environ. Sci. Technol. 45, 7962-7973.

Huang, H.L., Zhang, S.Z., Christie, P., Wang, S., Xie, M., 2010. Behavior of decabromodiphenyl ether (BDE-209) in the soil-plant system: uptake, translocation, and metabolism in plants and dissipation in soil. Environ. Sci. Technol. 44, 663-667.

Jones, C.G., Hare, J.D., Compton, S.J., 1989. Measuring plant protein with the Bradford assay. 1. Evaluation and standard method. J. Chem. Ecol. 15, 979-992.

Kim, M., Li, L.Y., Grace, J.R., Benskin, J.P., Ikonomou, M.G., 2015. Compositional effects on leaching of stain-guarded (perfluoroalkyl and polyfluoroalkyl substance-treated) carpet in landfill leachate. Environ. Sci. Technol. 49, 6564-6573.

Kwadijk, C.J.A.F., Korytár, P., Koelmans, A.A., 2010. Distribution of perfluorinated compounds in aquatic systems in The Netherlands. Environ. Sci. Technol. 44, 3746-3751.

Lechner, M., Knapp, H., 2011. Carryover of perfluorooctanoic acid (PFOA) and perfluorooctane sulfonate (PFOS) from soil to plant and distribution to the different plant compartments studied in cultures of carrots (Daucus carota ssp. sativus), potatoes (Solanum tuberosum), and cucumbers (Cucumis sativus). J. Agr. Food Chem. 59, 11011-110118.

Li, X.Y., Zhu, Y.H., Wu, T., Zhang, S.Z., Christie, P., 2010. Using a novel petroselinic acid embedded cellulose acetate membrane to mimic plant partitioning and in vivo uptake of polycyclic aromatic hydrocarbons. Environ. Sci. Technol. 44, 297-301.

Murano, H., Otani, T., Seike, N., Sakai, M., 2010. Dieldrin uptake and translocation in plants growing in hydroponic medium. Environ. Toxicol. Chem. 29, 142-148.

Ng, C.A., Hungerbuhler, K., 2014. Bioaccumulation of perfluorinated alkyl acids: observations and models. Environ. Sci. Technol. 48, 4637-4648.

Ng, C.A., Hungerbuehler, K., 2013. Bioconcentration of perfluorinated alkyl acids: how important is specific binding? Environ. Sci. Technol. 47, 7214-7223.

Rickers, J., Tober, I., Spener, F., 1984. Purification and binding characteristics of a basic fatty acid binding protein from Avena sativa seedlings. Biochim. Biophys. Acta $794,313-319$.

Rizov, I., Doulis, A., 2001. Separation of plant membrane lipids by multiple solidphase extraction. J. Chromatography A 922, 347-354.

Satchivi, N.M., Stoller, E.W., Wax, L.M., Briskin, D.P., 2006. A nonlinear, dynamic, simulation model for transport, and whole plant allocation of systemic xenobiotics following foliar application. IV: physicochemical properties requirements for optimum absorption and translocation. Pestic. Biochem. Physiol. 84, 83-97.

Sepulvado, J.G., Blaine, A.C., Hundal, L.S., Higgins, C.P., 2011. Occurrence and fate of perfluorochemicals in soil following the land application of municipal biosolids. Environ. Sci. Technol. 45, 8106-8112.

Spector, A.A., Santos, E.C., Ashbrook, J.D., Fletcher, J.E., 1973. Influence of free fatty acid concentration on drug binding to plasma albumin. Ann. N. Y. Acad. Sci. 226 247-258.

Stahl, T., Riebe, R.A., Falk, S., Failing, K., Brunn, H., 2013. Long-term lysimeter experiment to investigate the leaching of perfluoroalkyl substances (PFASs) and the carry-over from soil to plants: results of a pilot study. J. Agr. Food Chem. 61, 1784-1793.

Stevenson, C.N., MacManus-Spencer, L.A., Luckenbach, T., Luthy, R.G., Epel, D., 2006. New perspectives on perfluorochemical ecotoxicology: inhibition and induction of an efflux transporter in the marine mussel, Mytilus californianus. Environ. Sci. Technol. 40, 5580-5585

Sun, H.W., Gerecke, A.C., Giger, W., Alder, A.C., 2011. Long-chain perfluorinated chemicals in digested sewage sludges in Switzerland. Environ. Pollut. 159, $654-662$.

Vierke, L., Ahrens, L., Shoeib, M., Palm, W., Webster, E.M., Ellis, D.A., Ebinghaus, R., Harner, T., 2013. In situ air-water and particle-water partitioning of perfluorocarboxylic acids, perfluorosulfonic acids and perfluorooctyl sulfonamide at a wastewater treatment plant. Chemosphere 92, 941-948.

Wang, Z., Xie, Z.Y., Mi, W.Y., Möller, A., Wolschke, H., Ebinghaus, R., 2015. Neutral 
poly/per-fluoroalkyl substances in air from the Atlantic to the Southern Ocean and in Antarctic snow. Environ. Sci. Technol. 49, 7770-7775.

Washington, J.W., Yoo, H., Ellington, J.J., Jenkins, T.M., Libelo, E.L., 2010. Concentrations, distribution, and persistence of perfluoroalkylates in sludge-applied soils near Decatur, Alabama, USA. Environ. Sci. Technol. 44, 8390-8396.

Wen, B., Li, L.F., Zhang, H.N., Ma, Y.B., Shan, X.Q., Zhang, S.Z., 2014. Field study on the uptake and translocation of perfluoroalkyl acids (PFAAs) by wheat (Triticum aestivum L.) grown in biosolids-amended soils. Environ. Pollut. 184, 547-554.

Wen, B., Li, L.F. Liu, Y., Zhang, H.N., Hu, X.Y., Shan, X.Q., Zhang, S.Z., 2013. Mechanistic studies of perfluorooctane sulfonate, perfluorooctanoic acid uptake by maize (Zea mays L. cv. TY2). Plant Soil 370, 345-354.

Xia, X.H., Rabearisoa, A.H., Jiang, X.M., Dai, Z.N., 2013. Bioaccumulation of perfluoroalkyl substances by Daphnia magna in water with different types and concentrations of protein. Environ. Sci. Technol. 47, 10955-10963.
Yoo, H., Washington, J.W., Jenkins, T.M., Ellington, J.J., 2011. Quantitative determination of perfluorochemicals and fluorotelomer alcohols in plants from biosolid-amended fields using LC/MS/MS and GC/MS. Environ. Sci. Technol. 45, 7985-7990.

Zhang, L., Ren, X.M., Guo, L.H., 2013. Structure-based investigation on the interaction of perfluorinated compounds with human liver fatty acid binding protein. Environ. Sci. Technol. 47, 11293-11301.

Zhao, S.Y., Fang, S.H., Zhu, L.Y., Liu, L., Liu, Z.T., Zhang, Y.H., 2014. Mutual impacts o wheat (Triticum aestivum L.) and earthworms (Eisenia fetida) on the bioavailability of perfluoroalkyl substances (PFASs) in soil. Environ. Pollut. 184, 495-501.

Zhu, Y.H., Zhang, S.Z., Zhu, Y.G., Christie, P., Shan, X.Q., 2007. Improved approaches for modeling the sorption of phenanthrene by a range of plant species. Environ. Sci. Technol. 41, 7818-7823. 